\title{
Research developments in debris flow monitoring, modelling and hazard assessment in Italian mountain catchments
}

\author{
M. A. Lenzi \\ Department of Land and Agroforest Environments, University of Padova, \\ Italy
}

\begin{abstract}
Debris flows play an important role among natural hazards in the mountainous areas of Italy. This paper provides an overview of the recent research on debris flows conducted in Italy, taking into account both hydraulic and morphological studies. Moreover, the most encouraging research perspectives in this field are briefly presented, such as the monitoring in instrumented basins, the geotechnical analysis of the processes leading to debris flow initiation and modelling. Finally, three study cases are reported, with the aim of outlining the main characteristics of these phenomena and the consequent risk conditions in representative sites in the Italian mountains.
\end{abstract}

Keywords: Italy, debris flow, monitoring, natural hazards, modelling.

\section{Introduction}

Italy is a peninsula in southern Europe, whose territory covers $301,277 \mathrm{~km}^{2}$ and of which $75 \%$ consists of mountainous or hilly areas. Relief is high and differentiated: peaks on the Alps (Northern Italy) range between 2,700 and 4,800 $\mathrm{m}$ a.s.l., while on the Apennines (Central and Southern Italy), they vary between 2,000 and 2,800 $\mathrm{m}$ a.s.l. The Po River is the longest water course $(652 \mathrm{~km})$ and it crosses Northern Italy in an E-W direction, draining a basin of about $70,000 \mathrm{~km}^{2}$ Its average annual runoff is about $660 \mathrm{~mm}$; higher peak discharges reach values of about $10,000 \mathrm{~m}^{3} \mathrm{~s}^{-1}$ [1]. The Alps originated by compression and foreshortening of the margins between Africa and Europe. This processes of crustal shortening, which began in the late Mesozoic era (Upper Cretaceous) and continues up to the present, has led to the formation of thrust nappes of the crystalline basement and of its sedimentary cover complexes (carbonates, marls 
and sandstones) hundreds of kilometres northward since the Eocene age. Some of the rocks suffered intense regional metamorphism and granitic intrusives rose into the deformed pile of rocks. A subsequent compressive phase during the Oligocene-Miocene age led to the formation of the sedimentary Apenninic nappes, in which flysch facies prevail. Large areas of the Italian Peninsula are seismically active [1]. Most of Italy (Central and Southern Italy and the Islands) is characterized by a Mediterranean climate (warm, dry summer); in Northern Italy the climate is still Mediterranean-influenced, but with sufficient precipitation all year round. In the Alps and the Apennines, mountains strongly affect the climate conditions. Highest annual precipitation occurs in some areas of the Pre-alpine belt (up to about 3,000 mm) and on the western slope of the Northern Apennine. Low annual precipitation (less than $600 \mathrm{~mm}$ ) characterizes widespread areas of Southern Italy; low precipitation is also found in some locations of Northern Italy (e.g. in some valleys in the inner part of the Alps), as a consequence of local topographic conditions. Very high excesses of precipitation occur in several mountain ranges, resulting in favourable conditions for occurrence of flash floods, landslides and debris flows [1].

Debris flows are amongst the most frequent and serious natural disasters in the mountainous areas of Italy. These geomorphic processes, consisting of a mixture of water and sediment that moves as a viscous fluid down a torrent channel or a scree-slope, are highly destructive; their activity has caused substantial property damage and loss of lives in recent years as in the past, owing to the long history of human settlements in Italian mountain regions. Among the most destructive debris flows that have occurred in the Alps during the last 150 years, some of the most relevant case histories are given hereafter:

The Gonder Torrent: a debris flow of about 500,000 $\mathrm{m}^{3}$ destroyed 20 houses and claimed 39 lives in a village lying on the lower course of the steam (Aug. 17-18, 1891) [2]. The Tina Torrent: during a storm, a debris flow of about $500,000 \mathrm{~m}^{3}$ partially buried the village of Chiusa and caused extensive property damage (Aug. 9, 1921) [3]. The Chieppena Torrent: a very large volume debris flow occurred during a regional flood and most of the village of Strigno was buried (Nov. 4, 1966) [4]. The Inferno Torrent: a debris flow of about 750,000$1,000,000 \mathrm{~m}^{3}$ occurred in a basin of $0.2 \mathrm{~km}^{2}$ in the Western Italian Alps, destroying several houses (May 1983) [5]. During the May 1998 event in the Pizzo d'Alvano massif (Sarno, Southern Italy), hundred of soil slip-debris flows were triggered and impacted on the urbanised areas at the base of the massif, causing serious damage and numerous victims [6]. The October 2000 flooding and debris flow event in Valle d'Aosta: several villages were buried caused numerous victims [41]. In this paper, the most recent research developments relating to debris flow studies in Italy are reviewed.

\section{Debris flow research}

\subsection{Debris flows distribution}

Debris flows result from the mobilisation of loose debris by landsliding or by large water influxes, generally during high-intensity local precipitations, 
sustained regional rainstorms or rapid snowmelt. Once mobilised, the debris moves either down a torrent channel (channalised debris flows) draining watersheds which seldom exceed $10-20 \mathrm{~km}^{2}$, or on scree-slope (hill-slope debris flows) varying its paths from event to event. In the Alps, both types of debris flows (channalises and hill-slope) occur. In Central Apennines, debris flow can have the same characteristics of the Alpine ones, if occurring in carbonatic complexes, and very large boulders may also be present. In those cases where debris flows occur in flysch formations that extensively outcrop in the Apennines, the debris consists prevailingly of fine materials and can therefore be defined as mud-flows. Thus, debris flows can occur more or less anywhere in the mountainous areas of Italy, provided that the slope is steep enough an there is suitable amount of loose debris to be mobilised [1].

\subsection{Hydraulic studies on debris flows}

A review of the research in the field of debris flow mechanics and control was performed by Seminara and Tubino [7]. Experimental research on physical modelling of debris flows was carried out at the University of Trento, with particular attention both to theoretical aspects, such as the investigation similarity criteria, and to practical problems concerning torrent control works (e.g. the analysis of the dynamic impact of debris flows on structures and the development of more effective check dams) [8-10]. Tubino and Lanzoni carried out observations of flow depth, average velocity and bulk concentration in the flow of water and granular mixtures along a laboratory chute [11]. Lamberti and Schippa developed and experimental rheometer in order to analyse the rheological properties of debris flows [12]. A mathematical model for movements of debris flows, based on the kinematic wave theory, was devised by Arattano and Savage [13]. Other numerical models were developed during the last two decades based on different assumptions [14-19]. Studies and researches on critical conditions of bed sediment entrainment due to debris flow, factors triggering debris flow, the determination of rheological characteristics of debris flow, configurations of debris-flow fan and run-out distances, based on flume tests, numerical and dimensional analysis, has also been carried out in Italy by many Authors [20-26].

\subsection{Geomorphological studies on debris flows}

Geomorphological fields investigations on debris flows are referred to in several technical and research reports concerning floods events in the Italian Alps [2729]. Geological and geomorphological settings of the affected areas are outlined, with reference to morphologic and sedimentologic characteristics of the debris flow and a description of the damage caused. These fields studies, combined with morphometric analysis of the drainage basins and alluvial fans and including historical investigations on past flow events, contributed to our knowledge of debris flow distribution and characteristics in the Italian Alps [3031]. Of course, more detailed documentation is available in the event that involve urban settlements. Among these case histories, data related to 159 debris 
flow events were selected and analysed, providing the following general considerations [30]:

1) $66 \%$ of debris flow events occur from July to September.

2) Affected basins mostly lie in areas having a continental precipitation regime, characterized by greatest precipitation in summer and minimum precipitation (mostly occurring as snowfall) in winter. This precipitation regime is typical of the inner part of the Alpine Range

The observation conducted on the most severe debris flow events that occurred in the last five decades outlines that [32]:

1) $85 \%$ of affected basins have areas ranging from $0.5 \mathrm{~km}^{2}$ to $13 \mathrm{~km}^{2}$.

2) $55 \%$ of the channels have an average slope ranging from $11^{\circ}$ to $22^{\circ}$, $37 \%$ reach gradients of $35^{\circ}$.

3) $45 \%$ of triggering mechanisms are represented by shallow landslides in the valley heads; $43 \%$ is represented by dam breakage of check dams or debris deposits clogging the channel.

4) $42 \%$ of debris flow events reoccur in the same streams with a period equal to or higher than 50 years, whereas $6 \%$ ranges from 5 to 15 years. In the remaining percentage, based on available information, it is only possible to establish that at least one event occurred in the last five decades. This fact is of utmost importance in identified hazards sites, because the return intervals of debris flows could be sufficient long in relation to the development of an urbanized area, so that debris flow hazards may not be perceived.

The problem of flow type identification on alluvial fans (i.e. debris flows or bedload transport), which is relevant for defining hazard types was analysed in Northeastern Italy through a morphometric procedure combined with field surveys [33-35]. The study followed a similar approach developed in the Canadian Rocky Mountains [36]. The analysed sample (52 cases) made it possible to classify alluvial fans into three groups: debris flow dominant fans, mixed fans and fluvial fans. In mixed fans, bedload transport and hyperconcentrated flow as well as debris flow phenomena may occur, the latter generally with lower frequency. Three groups are separated clearly enough in a plot of the fan slope versus a basin gradient index (Melton ruggedness number), providing a graphical implement for preliminary discrimination of alluvial fans on the basis of the expected prevailing flow processes. The comparison of expected behaviour with flow processes known from historical information in several basins confirms the suitability of this method.

Debris flows in the area of the Central Apennines were investigated taking into account several hazard and risk assessment aspects, such as historical events, rainfall characteristics and the evolution of debris flow gullies [37]. Morphological characteristics of debris flows in Southern Italy were studied by different Authors [6], [22], [38], outlining the main causes. In all cases, besides the tectonic and lithological conditions which undoubtedly contributed to these processes, other anthropogenic causes, such deforestation and the processes of abandoning arable lands, thus causing alteration of local groundwater hydrology, play an important role in developing debris and mud flows [22]. 


\subsection{Debris flow research perspectives}

Sediment transport in steep, small $\left(<10 \mathrm{~km}^{2}\right)$ catchments of the Alps is often represented by both Newtonian (water floods with suspended and bedload transport) and non-Newtonian (debris and mud flow) behaviour, passing through hyper-concentrated flood events, characterized by intermediate characteristics. Despite significant diversity as to their transport mechanics, the monitoring activity of such impulsive, high-energy processes in remote areas poses problems that are similarly complex. Further, the availability of long-term series of data (e.g. volumes, discharge, velocity) is crucial in order to provide statistically significant analysis and predictions, thus making experimental measuring stations highly valuable for the scientific community as well as for the local agencies dealing with torrent control and land use planning. Field observations and experimental data on debris flows (e.g. debris flow magnitude, flow velocity, sequence and shape of surges) recorded in instrumented streams are of utmost important for the development of research works. In Italy, like in other European countries, there is a lack of such experimental data, with a few exceptions [44-48]. Field data on debris flows and the estimation of debris flow magnitude are essential steps in the assessment of debris flow hazards, and also for both modelling and development of attenuation measures. These topics need an improvement in the future. Studies having implications of geotechnical nature have been carried out in other countries [39, 40-42, 43], whereas they have so far undergone limited development in Italy. However, recent contributions to the mechanics of debris flow initiation has investigated the influence of the mechanical behaviour of sediments at the onset of a debris flow, particularly analysing the shear resistance variation of a granular soil in relation to the initial densities and to the collapse potential of the soil [20]. Other recent researches have been carried out in Italy on incipient sediment motion at high slopes [23, 49,50] but need more applications.

Mathematical models, based on systems of differential equations, are widely used for simulation of debris flow initiation, propagation and deposition, both in field applications (prediction of run out, design of countermeasures, etc.) and in laboratory research. The numerical solution of the equations can be very difficult, due to the complexity of the models themselves and to the variability of physical unknowns in time and space, consequently many numerical methods have been developed. However, the choice of the most reliable rheological model could be more important than the choice of numerical method [51, 52].

In the approach to the matter of hydro-geological risk is also very important to know the requirements expressed by institutional bodies dealing, at different levels, with land planning, soil protection and civil defence [53]. Technicians working for regional Administrations and basin Authorities highlighted that, if the necessity is clear to ensure people safety and to safeguard the territory from more and more frequent landslides and floods, there is not, on the other hand, a comprehensive understanding of general criteria imposed by law, regarding methodologies to objectively recognize and outline areas at risk for floods, landslides and debris flows. Directions springing from these laws are generally 
well detailed in terms of hazard's classes definition, especially for hydraulic risk, but show considerable lacks in the determination of field survey and eventmodelling methodologies for an objective outlining of areas at risk.

\section{Papers in this session}

Four papers are presented in this theme; these will be presented in turn. One paper regards the long-term series on sediment volumes (17 and 20 monitoring years) in two instrumented channels in the Eastern Italian Alps (Moscardo and Rio Cordon torrents, featuring debris flow and bedload events respectively). Three study cases, representative of different situations occurring in the Dolomites in the Western Italian Alps and in Gargano watersheds (Southern Italy), are briefly referred to in order to outline the basic characteristics of debris flows and consequent risk conditions. The remarkable differences in the frequency and characteristics of debris flow phenomena have to be referred to the strong variability in local geological and geomorphological conditions.

\subsection{Mao et al.}

Mao et al. [54], reports results from experimental stations located in two streams of the Eastern Italian Alps: the Rio Cordon creek $\left(5.0 \mathrm{~km}^{2}\right)$ and the Moscardo Torrent $\left(4.1 \mathrm{~km}^{2}\right)$. The former is a monitoring station for water and sediment transport rates operating since 1986, whereas the latter was set up in 1989 to record data on debris flows. The measuring station installed on the Rio Cordon works based on the separation of coarse bedload from water with suspended sediment and fine bedload. The equipment installed in the Moscardo Torrent for monitoring debris flows includes ultrasonic sensors for the measurement of flow stage, ground vibration sensors that record ground vibrations caused by debris flows, and a video camera. Overall, 21 bedload-transporting events have been recorded by the Rio Cordon station from 1986 to 2004. In the Moscardo Torrent, from 1990 to 199815 debris flows occurred, 14 of which were recorded by the installed gauges. A comparison between the two basins is reported by the Authors, based on magnitude, peak discharge and frequency of occurrence of the flood events.

\subsection{D’Agostino and Tecca}

D'Agostino and Tecca [55]. The two-dimensional flood routing model FLO-2D $[56,57]$, with the capabilities of simulating non-Newtonian sediment flows, is becoming more widely used to route debris flows over alluvial fans of alpine torrents and to delineate hazard areas of inundation. Nevertheless the different applications described in literature are not suitably comparable, because they base on different assumptions related to the numerous parameters governing the debris flow simulation. D'Agostino and Tecca reports the applications of the FLO-2D computer model and discusses the assumptions made for the replication of two well documented debris flow events in the Dolomites, Eastern Italian Alps. These two applications have enhanced the experience for the requirements 
of model input data in small alpine catchments, in particular the assessment of the main rheological parameters of flows, that are crucial in the design of debris flow countermeasures; they lead to propose a simplification in choosing the FLO-2D rheological parameters.

\subsection{Segato et al.}

Segato et al. [58], used three different methodologies for the determination and the outlining of areas prone to debris flow risk. The first is based on a comprehensive analysis of all variables (morphological, geological, geomorphologic, hydraulic, hydrologic, and topographic) involved in the definition of basin and fan characteristics, integrated with a modelling application. The second methodology maintains the first modelling application, which individuates the overflowing points of the flow from the main channel, and is then based on the definition of the "geomorphologic attitude" of the fan area to convey the moving material in a certain direction, as a function of fan morphology (topography, slope, etc.), main channel features and land use. The third method applies the mathematical model FLO-2D. The outputs of the three methodologies have been compared by the Authors, in order to evaluate limits and highlights of each one of them, and to compile a methodological procedure for fan-mapping.

\subsection{Gentile et al.}

Gentile et al. [59], describes the southern side of the Gargano promontory (Puglia Region, Southern Italy), crossed by several torrents shaped in calcareous formations prone to mechanical erosion caused by heavy rainfalls. In this area, characterized by typical Mediterranean conditions, no monitoring is provided. During heavy rainstorms materials, including blocks of rock, move from the hills lopes and reach the valley areas. The detachment of coarse materials is also favoured by the lack of vegetal cover and the exposition of hills slopes. As a consequence of catastrophic events, some watersheds have been objects of management works (check dams, gabions or concrete banks, sills). Gentile et al. describes an overview of debris flow events with regard to the Pulsano torrent, to characterize the debris flow phenomena and related hazard. The risk assessment procedure took into consideration the hazard mapping, the vulnerability evaluation through the estimation of the properties and structures exposed to damage. A comparison between alternative scenarios was also made by the Authors to evaluate the influence of the hydraulic works on debris flow hazard using the two-dimensional model FLO-2D.

\section{References}

[1] Marchi L., Tecca P.R. \& Liu Xilin, Recent developments in debris flow research in Italy. Chinese Geographical Science, 5, (3), pp. 275-287, 1995. 
[2] Eisbacher G.H., Claque J.J., Destructive mass movements in high mountains: hazard and management. Geol. Survey of Canada, Paper 8416, Otawa: Canadian Government Publishing Centre, pp 1-230, 1984.

[3] Baselli G., La catastrofe di Chiusa d'Isarco e le opere di riparazione e di prevenzione eseguite. Giornale del Genio Civile 61, pp. 619-634, 1923.

[4] Venzo G.A., Largaiolli T., Il bacino del Chieppena (Trentino)Stratigrafia-Tettonica-Geomorfologia e Idrologia-Fenomeni franosi. Memorie del Museo Tridentino di Scienze Naturali, 17 (2), pp. 1-103, 1968.

[5] Mortara G., Ricerche sulle colate detritiche torrentizie (debris flow) in ambiente alpino. CNR-GNDCI, Rapporto 1992/93, pp. 287-302, 1994.

[6] Del Prete M., Guadagno F.M. \& Hawkins A.B., Preliminary report on the landslides of 5 May 1998, Italy. Bull. Eng. Geol. Env., 57, 113-129, 1998.

[7] Seminara G. \& Tubino M., Debris flow: meccanica, controllo e previsione. Roma, CNR-GNDCI, pp. 1-220, 1990.

[8] Armanini A. Physical modelling of debris flow. Int. Symp. on "Debris Flow and Flood Disaster protection”, Emeishan City, China, pp. 1-8, 1991.

[9] Armanini A., DellaGiacoma F. \& Ferrari L., From the check dam to development of functional check dams. In: Fluvial hydraulics of mountain regions, Lecture Notes in Earth Sc., Springer-Verlag 37, 331-334, 1991.

[10] Armanini A. \& Scotton P., Experimental analysis on the dynamic impact of a debris flow on structures. INTERPRAEVENT 1992, Vol. 6., 107-116, 1992.

[11] Tubino M. \& Lanzoni S., Rheology of debris flows: experimental observations and modelling problems. Excerpta, 7, pp. 201-236, 1993.

[12] Lamberti A. \& Schippa L., Preliminary experimental results on the rheology of debris flows. Int. Workshop on Floods \& Inundations related to large Earth Movements, Trento, Italy, A10.1-A10.15, 1994.

[13] Arattano M \& Savage W.Z., Modelling debris flows as kinematic waves. Bull. IAEG, 49, pp. 3-13, 1994.

[14] Fraccarolo L. \& Toro F., Experimental and numerical assessment of the shallow water model for two-dimensional dam-break type problems. $J$. Hydr. Res., 33, 843-864, 1995.

[15] Papa M. \& Lamberti A., Application of debris flow numerical modelling to Acquabona catchment. Proc. Final Debris Flow Risk Project Meeting, Università di Bologna, Bologna, Italy, 1999.

[16] Fraccarolo L. \& Papa M., Numerical simulation of real debris-flows events. J. Phys. Chem. Earth (B), 25 (9), 757-763, 2000.

[17] Archetti R. \& Lamberti A., Assessment of risk due to debris flow events. Natural Hazards Review, Vol 4, (3), 115-125, 2003.

[18] Fraccarollo L., Capart H. \& Zeck Y., A Godunov method for the computation of erosional shallow water transient. Int. Journal of Numerical Methods in Fluids, 41, 951-976, 2003. 
[19] D’Ambrosio D., Di Gregorio S., Iovine G., Lupino V., Rongo R. \& Spataro W., First simulation of the Sarno debris flows through cellular automata modelling. Geomorphology, 54, 91-117, 2003.

[20] Genevois R., Marchi L. \& Tecca P.R., Influence of mechanical behaviour of soils in debris flow initiation. XX IUFRO Congress, Finland, 12-25, 1995.

[21] Coussot F., Laigle D., Arattano M., Deganutti A. \& Marchi L., Direct determination of rheological characteristics of debris flow. J. of Hydr. Eng., ASCE, 124, (8), 865-868.

[22] De Vita P. \& Piscopo V., Influences of hydrological and hydrogeological conditions on debris flow in peri-vesuvian hillslope. Natural Hazards \& Earth System Sciences 2, 27-35, 2002.

[23] Papa M., Egashira S. \& Itoh T., Critical conditions of bed sediment entrainment due to debris flow. Natural Hazards \& Earth Systems Sciences 4, 469-474, 2004.

[24] Berti M. \& Simoni A., The support of monitoring for the computation of the debris-flow rainfall threshold. Geophy. Res. Abstracts, Vol. 7, 06320, 2005.

[25] Parson J., Whipple, K. \& Simoni, A., Experimental study of the granularflow, fluid-mud transition in debris flows. J. of Geol., 109, 4, 427-447, 2001.

[26] Buthurst J.C., Crosta G., Garcìa-Ruiz J.M., Guzzetti F., Lenzi M.A. \& Rìos S., DAMOCLES: Debris-fall assessment in mountain catchments for local end-users. In: Rickenmann \& Chen (eds), Debris flow hazards mitigation: mechanism prediction and assessment. Rotterdam, 10731083, 2003.

[27] Mortara G., Sorzana P.F. \& Villi V., L'evento alluvionale del 6 agosto 1985 nella valle del fiume Inarco tra Fortezza ed il passo del Brennero (Alto Adige). Memorie di Scienze Geologiche, 38, 427-457, 1986.

[28] Arattano M., Deganuti A., Godone F., Marchi L. \& Tropeano D., L'evento di piena del 23-2 settembre 1990 nel bacino del Fella (Alpi Giulie). Bollettino dell'Associazione Mineraria Subalpina, 28 (4), $627-$ 763, 1991.

[29] Marchi L., Pasuto A., Silvano S. \& Tecca P.R., Nota su alcuni eventi alluvionali verificatisi durante il 1989 nell'Italia Nord-orientale. Bollettino dell'Associazione Mineraria Subalpina, 27 (1-2), 205-228, 1990.

[30] Govi M., L'assetto morfologico nella valutazione dei rischi connessi ad eventi idrologici estremi. Seminario su: "La pianificazione di bacino", Genova, Italia, 5-38, 1979.

[31] Govi M., Marchi L., Mortara G., \& Turitto O., Ricerche sulle colate detritiche torrentizie (debris flow) in ambiente alpino. Roma, CNRGNDCI, Rapporto 1990/91, 405-420, 1992.

[32] Govi M., Mortara G. \& Sorzana P.F., Crues et laves torrentielles avec des consequences humaines graves ou catastrophiques dans les Alpes Italiennes. 25th Congr. Int. Geographie "Les Alpes". Paris, France, 31 39, 1984. 
[33] Marchi L., Pasuto A. \& Tecca P.R., Flow processes on alluvial fans in the Eastern Italian Alps. Z. Geomorph. N. F., 37,(4), 447-458, 1993.

[34] Marchi L. \& Tecca P.R., Alluvial fans of the Eastern Italian Alps: morphometry and depositional processes. Geod. Acta, 8 (1), 20-27, 1995.

[35] Moscariello A., Marchi L., Maraga F. \& Mortara G., Alluvial fans in the Italian Alps: sedimentary facies and processes. Spec. Publs. Int. Ass. Sediment, 32, 141-166, 2002.

[36] Jackson L.E., Kostaschuck R.A. \& McDonald G.M., Identification of debris flow hazard on alluvial fans in the Canadian Rocky Mountains. Geol. Soc. Of America Review.; In: Engineering Geology, 7, 115-124, 1987.

[37] Guzzetti F. \& Cardinali M., Debris flow phenomena in the Central Apennines of Italy. Terra Nova, 3, 619-627, 1991.

[38] Alexander D., On the causes of landslides: human activities, perception and natural processes. Environ. Geol. Water Sc., 20 (3), 165-179, 1992.

[39] Takahashi T., Evaluation of the factors relevant to the initiation of debris flow. New Delhi, India, 3, 136-140, 1980.

[40] Takahashi T., Initiation and flow of various types of debris flow. In: Wieczorek \& Naeser (eds), Debris flow hazards mitigation: mechanism prediction and assessment. Balkema, Rotterdam, 15-25, 2000.

[41] Ratto S., Bonetto F. \& Comoglio C., The October 2000 flooding in Valle d'Aosta (Italy): event description and land planning measurements for the risk mitigation. J. of River Basin Management, Vol. 1, (2), 105-111, 2003.

[42] Sassa K., The mechanism starting liquefield landslides and debris flow. Proc. Int. Symp. Landslides, Toronto, Canada, 2, 349-354, 1984.

[43] Ellen S.D. \& Fleming R.W., Mobilization of debris flow from soil slips, San Francisco Bay region, California. Geol. Soc. America Rew. In Engrg. Geol, 7, 31-40, 1987.

[44] Rickenmann D., Empirical relationships for debris flows. Natural Hazards, 19, 47-77, 1999.

[45] Hurlimann M., Rickenmann D. \& Graf C., Field data and monitoring data of debris flow events in the Swiss Alps. Can. Geothech. J., 40, 161-175, 2003.

[46] Berti M., Genevois R., Simoni A. \& Tecca P.R., Field observations of a debris flow event in the Dolomites. Geomorphology, 29, 265-274, 1999.

[47] Marchi L., Arattano M. \& Deganutti A., Ten years of debris flow monitoring in the Moscardo Torrent (Italian Alps). Geomorphology 46, 117, 2002.

[48] Marchi L. \& D’Agostino L., Estimation of debris flow magnitude in the Eastern Italian Alps. ESPL Vol. 29, 207-220, 2004.

[49] Armanini A. \& Gregoretti C., Incipient sediment motion at high slopes in uniform conditions. Water Resources Research 41, 1-8; 2005.

[50] Bagato A., Dalla Fontana G. \& Gregoretti C., Analisi del verificarsi di condizioni di innesco di colate detritiche per mobilitazione di depositi detritici al fondo di canali naturali. XXI Congresso di Idraulica $e$ Costruzioni Idrauliche; 7-10 Settembre 2004, Vol. 1, 341-347, 2004. 
[51] Rickenmann D. \& Koch T., Comparison of debris flow modelling approaches. Proc. First Int. Conf. on Debris Flow Hazards Mitigation; San Francisco, USA, ASCE, pp. 576-585, 1997.

[52] Arattano M., Franzi L. \& Marchi L., On the influence of rheology on debris flow mathematical simulation: a real case. Geophy. Res. Abstracts, 7, 2005.

[53] Ratto S. \& Bonetto F., Forecasting and prevention measures for the hydrogeological risk mitigation and land safety in Aosta valley. $10^{\circ}$ Congress INTERPRAEVENT 2004; Trento; 24-27 May 2004, IX 159-170, 2004.

[54] Mao L., Cavalli M., Comiti F., Marchi L. \& Arattano M., Long-term monitoring of bedload and debris flows in two small catchments of the Eastern Italian Alps, (this volume).

[55] D'Agostino V. \& Tecca P.R., Some considerations on the application of the FLO-2D model for debris flow hazard assessment, (this volume).

[56] O'Brien J.S., Julien P.Y., Fullerton W.T., Two-dimensional water flood and mudflow simulation. J. of Hydr. Eng., ASCE, 119(2), pp. 244-259, 1993.

[57] FLO-2D, 2-Dimensional Flood Routine Model Manual. Version 2004.10. FLO-2D Software Inc., Nutrioso, AZ 85932, 2004.

[58] Segato M., Mao L., Coccato M., Lenzi M.A. \& D’Agostino V., Operative approaches for debris flow modelling and hazard assessment, Laures watershed, Valle d'Aosta, Italy, (this volume).

[59] Gentile F., Bisantino T., Puglisi S. \& Trisorio Liuzzi G., Analysis and modelling of debris flows in Gargano watersheds (Puglia RegionSouthern Italy), (this volume). 